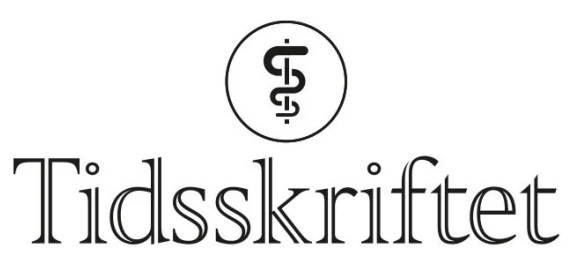

DEN NORSKE LEGEFORENING

\title{
Fortellinger om og for livet
}

\author{
ANMELDELSER
}

RENATE PETTERSEN

Oslo universitetssykehus, Aker

Avdeling for rehabilitering og geriatri

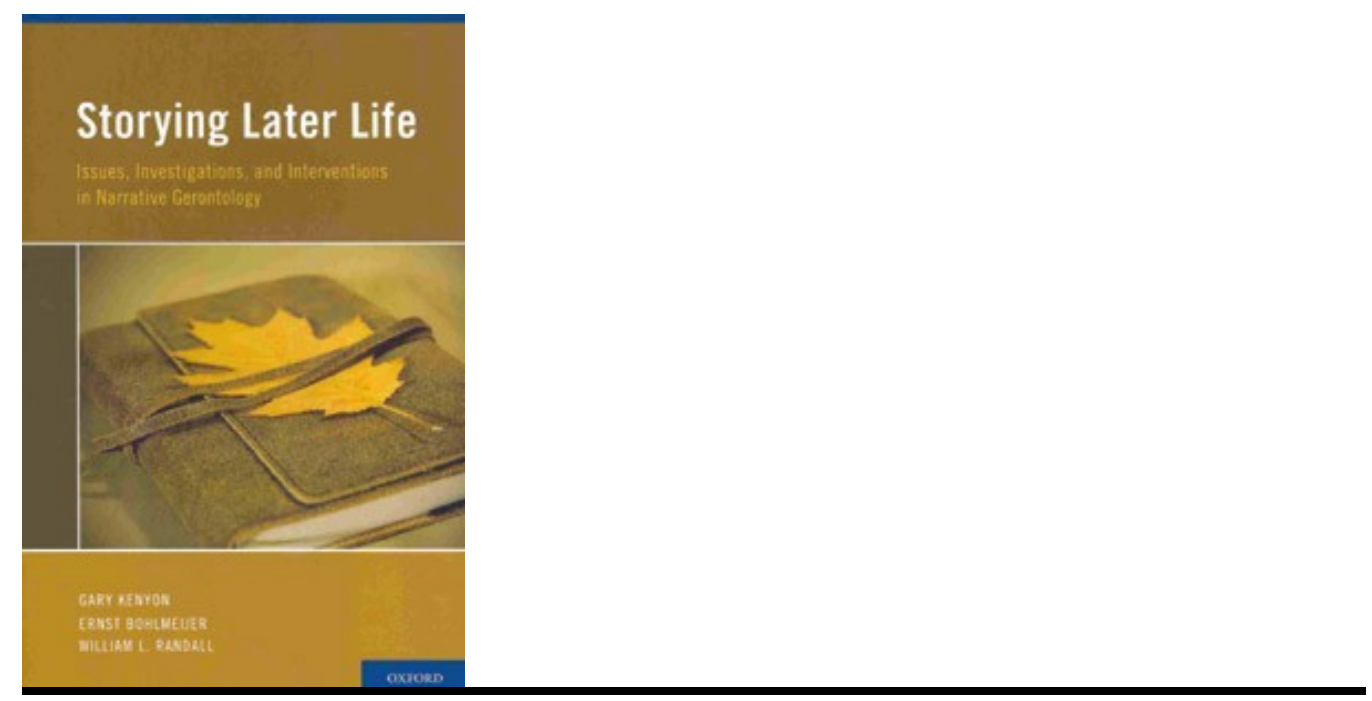

Kenyon, Gary

Bohlmeijer, Ernst

Randall, William L.

Storying later life

Issues, investigations, and interventions in narrative gerontology. $424 \mathrm{~s}$, tab, ill. Oxford:

Oxford University Press, 2011. Pris GBP 33

ISBN 978-0-19-539795-6

Boken er en innføring i narrativ gerontologi, en forholdsvis ung gren i læren om aldring og dens mangfoldige aspekter. I denne grenen utforsker forfatterne de biografiske dimensjonene av det å bli gammel, dvs. den indre opplevelsen og dens verbalisering enten muntlig eller skriftlig - av egen livshistorie og nåværende situasjon. 
Redaktørene har solide kunnskaper. Professor Gary Kenyon er en av grunnleggerne av narrativ gerontologi. Kapittelforfatterne er knyttet til akademiske miljøer i Canada, USA, Storbritannia og Nederland. Bidragene kommer overveiende fra områdene mental helse, atferdsfag og sosiologi, men også indremedisin, sykepleie, etikk og helseadministrasjon er representert.

Det er tre hoveddeler: viktige temaer, utforskninger og intervensjoner. Man kan lese kapitlene innen hver del uavhengig av hverandre. De har overkommelig omfang og rikelig med referanser. Det er få, men godt forståelige tabeller og illustrasjoner.

I temadelen belyser forfatterne hvordan mennesker som har levd en stund, kan oppfatte sitt liv: alt fra blindvei, villfarelse, misforståelse, skyld og soning, nedbrytning og forfall til nyorientering, ny mening og oppfyllelse. Slike oppfatninger er knyttet til samfunnsverdier, skiftende roller og sosiale rammer, følelsesmessige erfaringer og kroppens og sinnets helse. På ulike vis formidler forfatterne at et liv ikke består av en rekke enkelthendelser for oss, men at vi alltid legger en mening i disse og forsøker å knytte dem sammen til et større hele; en livsfortelling. Denne prosessen pågår hele tiden. Erindringen av fortiden er ikke fastspikret, men endres med nye erfaringer og meningen vi ilegger dem. Hos demensrammede mennesker vil denne fortellingen gradvis forsvinne, og det er det som skaper de største utfordringene for oss andre i kommunikasjonen med dem.

Utforskningsdelen inneholder blant annet studier om kroppsoppfatning, om kjønnsforskjeller i måten å presentere sin livshistorie på, og hvordan eldre kvinner opplever ny livsutfoldelse i en samfunnsengasjert gruppe (the raging grannies). Forfatterne presenterer metoder som reminisens- og skrivegrupper, gruppesamtaler for mennesker med krigstraumer og erindringsarbeid i parterapi hos eldre. Kapitlene er dels skrevet som vitenskapelige artikler, dels som kasuistikker.

Kapitlene i intervensjonsdelen er for meg de mest gripende - fordi forfatterne her viser at det gjennom forskjellige erindrings- og fortellermetoder er mulig å få gamle, kronisk syke mennesker og deres pårørende til å se konstruktive sammenhenger i fortiden, å oppdage at de har tilført samfunnet noe verdifullt, å forsone seg med forholdene slik de er, og finne en indre likevekt. Også alvorlig demente kan ha glede av det: Selv om deres egen fortelling er borte, kan de snakke om kjente gjenstander eller situasjoner og gi sin personlige vurdering av dem. Slik oppleves mening her og nå.

Jeg anbefaler boken for alle som arbeider med gamle syke. Den gir ettertanke, inspirasjon og håp. Fortellingen fortjener mer rom, og det må det legges til rette for.

Publisert: 20. mai 2011. Tidsskr Nor Legeforen. DOI: 10.4045/tidsskr.11.0370

(C) Tidsskrift for Den norske legeforening 2023. Lastet ned fra tidsskriftet.no 26. april 2023. 